\title{
DIALECTAL ELEMENTS IN THE VOCABULARY OF THE UYGHUR KHANATE INSCRIPTIONS
}

\author{
ERHAN AYDIN \\ İnönü University, Malatya, Turkey, Faculty of Science and Literature, \\ Department of Turkish Language and Literature, \\ e-mail: erhan.aydin@inonu.edu.tr
}

One of the significant problems with Old Turkic inscriptions is that it is not known by which peoples' or tribe's Turkic language the inscriptions were written in. Although among the clans and persons who wrote and erected the large inscriptions of the Turkic and Uyghur Khanates, those of Köl Tegin, Bilge Kaghan, Şine Usu, Tariat, Tes and Karabalghasun I were identified, the peoples or clans having erected the other inscriptions are mostly unknown. The most serious problem encountered by researchers in consideration of the tribal seals present in the inscriptions is the uncertainty whether the seal belonged to the tribe that wrote or erected the inscription, or the tribe that was in power at that time.

This paper investigates the inscriptions of the Uyghur Khanate. Our scrutiny is based on the examination of the peculiarities of the Uyghur Khanate inscriptions which cannot be observed in any other inscriptions of Mongolia, Yenisei, Altai and Kyrgyzstan. By substituting these peculiar words with other words to be found in other inscriptions, an attempt has been made to prove that these words are Uyghur dialectal words. After an inquiry whether the words were used subsequent to the runic period, etymological suggestions concerning the words have also been put forward.

Key words: Old Turkic, Old Turkic inscriptions, Uyghur Khanate, vocabulary, dialectal elements.

\section{Introduction}

One of the basic problems with Old Turkic inscriptions is the fact that almost all of them are undated, the best example being the inscriptions of the Yenisei Region. An additional problem is that in most cases it is difficult to identify the Turkic people or clan that wrote or erected them. Although some of the clans and persons who wrote and erected the large inscriptions of the Turkic and Uyghur Khanates, those of Köl Tegin, Bilge Kaghan, Şine Usu, Tariat, Tes and Karabalghasun I were identified, the peoples or clans erecting the other inscriptions are for the most part unknown. Studies that 
treated the seals of these inscriptions have met a major dilemma since one can by no means ascertain whether the seals belonged to the clan of the individual who erected the inscription or to the clan in administration. For instance, although the inscriptions of the Yenisei region, a significant terrain for Old Turkic inscriptions, were classified in a numerical order, I. V. Kormušin (1997) in his book Тюркские енисейские эпитафии, текстьл и исследования arranged the inscriptions according to their seals, not in the numerical order. The underlying idea of Kormušin's method was that the inscriptions bearing the same or similar seals were written by the same clan or people. However, it is rather difficult to identify the people or clan by the seal since there is no definitive information on the seals of the clans in the writing of Mahmūd al-Kāshgharī's Dīwān Lughāt al-Turk. Besides, the seals depicted by Kāshgharī were specific to Oghuz clans. Thus the problem is related to the inscriptions found in Mongolia, Altai and Kyrgyzstan. Inscriptions bearing the same stamp might have been written by the same people, however, they might as well bear the seal of the administering or ruling clan. Perhaps the only seals we could be certain about are the Uyghur clan seals, since the inscription on the northern side of the ŠU inscription bears the same seal as the Chinese-Uyghur epitaph found in Xi'an.

There is no doubt that the Tes, Ta, ŠU and Karabalghasun I (QB I) inscriptions were documents of the Uyghur Khanate. The seal on the Qar1 Čor epitaph, discovered at Xi' an towards the end of 2012, replicated the seal found on the northern side of the ŠU inscription, showing that the Uyghurs had erected both inscriptions. The Karabalghasun II, Sevrey, Sudji, Hoyto - Tamir (HT), Gurvaljiyn-Uul and Arhanan inscriptions are also regarded by some as artifacts of the Uyghurs.

In this paper research will be made into single words and phrases found on Uyghur Khanate inscriptions. Attempt is made to prove that these words and phrases do not occur on the major Turkic inscriptions such as Köl Tegin, Bilge Kaghan, Tonyukuk, Ongi and Küli Čor, but other words were used in their stead. Based on this fact the paper arrives at the conclusion that the special words on Uyghur Khanate inscriptions unattested elsewhere must have been dialectal elements of the Uyghur language. Twenty-four words will be scrutinised below with a special view to their possible etymologies.

\section{The Word Material}

1. adın 'other' (Tes E 2).

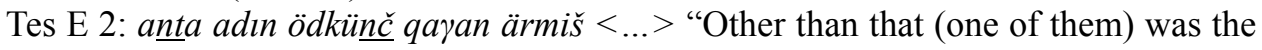
false khan $<\ldots$...".

T. Tekin (1990, p. 394) corrected the spelling as anta adın, stating that S. Kljaštornyj's spelling which connected the two words as antadan cannot be attested in any area of the Turkic languages. However, M. Erdal (2004, p. 204) still reads it as antadan $\sim$ antadın. Erdal's reference should be antada $\sim$ muntada, a usage common in Uyghur texts. 
This word, commonly observed in Uyghur texts, was first analysed by W. Bang (1980, p. 30) who deconstructed it as $* a d-(l) n$ and regarded the suffix $-n$ as a suffix forming a deverbal noun: $<$ adına- $<$ adına $u$. In addition, Bang claims that the suffix $+s I G$ was equivalent to ${ }_{s} I$ in Ottoman in the form adınč $r \gamma<$ adınsı $\gamma$ and gives the examples of ärkäksi (masculine), qadınsı (feminine). DTS (p. 10) cites examples from the Uyghur literature with the meaning of 'другой, иной'. After citing Bang's view, K. Röhrborn (UW, pp. 48-51) presents examples formed with the case suffix in Uyghur texts. Y.-S. Li (2004, pp. 59-60) cautiously claims that the word has been conjugated from the verb *ad- 'to be otherwise' using the gerundial suffix $-{ }^{o} n$ and used with the ablative suffix. Li's examples also go back only as far as the Uyghur period. $\mathrm{Li}$, after giving examples from ancient periods, refers to the modern Turkic forms such as Yak. atın, Dolg. atın.

According to Erdal (2004, p. 160) the word adın-ayu 'other(s)' is derived from the word adın using the collective suffix. He also states that the word adin should basically derive from the verb adır- 'to separate' (op. cit., p. 334). For adınč $r$ see ED p. 63 and UW p. 51.

2. ančıp 'afterwards' (Tes N 2, Tes E 3, ŠU E 7, 8, ŠU W 1, 4, 5).

Tes N 2: anıy eli üč yüz yıl el tutmiš ančlp bodunı bardl "His homeland, homeland for three hundred years, afterwards its people left".

Tes E 3: el tutdı ančı ıp yašı tägdi "he held (organised) the homeland. Afterwards his age added up (died)".

ŠU E 7: tarduš tölis bodunqa bertim ančıp bars yılqa čik tapa yorıdım "I appointed (them as administrators) to the Tarduš and Tölis tribes. Afterwards, in the year of the leopard (750) I marched towards the Čik".

ŠU E 8: bälgümün bitigimin anta yaratıtdım ančlp ol yıl küzün ilgärü yorıdım "I created my seal (and) inscription there. Afterwords I marched towards east in that year's autumn".

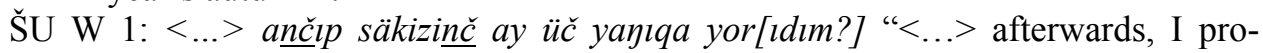
ceeded on the third day of the eighth month".

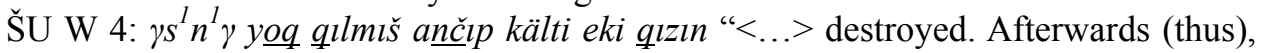
came. With two daughters".

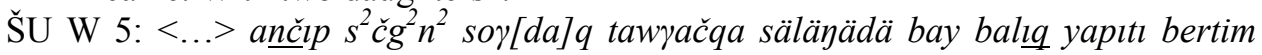
" $<\ldots>$ afterwards $<\ldots>$ I came to procure (the city of) Baybalık at the Selenge (river) for the Sogdian(s) (and) Chinese".

In addition to these seven examples from the Uyghur Khanate inscriptions, the word was also attested in Bichiktu-boom X (A 77) of the Altai inscriptions. Albeit the line was not very clear, Tybykova-Nevskaya-Erdal (2012, p. 64) read and explained the meaning of ančı as 'так'.

Clauson (ED, pp. 173b-174a), stated that the word was ančı from anča ärip, and the meaning could be interpreted as 'this being so', 'so much for that'. Since Clauson exemplifies his thesis with the ŠU inscription, the Irq Bitig and scripts from later periods, it has been claimed that it was not used in periods later than the Uyghur era. Erdal (2004, pp. 201, 327) noted that the word means 'doing that, thereupon' and 
he claims that the word $ı n c ̌ p$, used extensively in Uyghur texts, was formed by add-

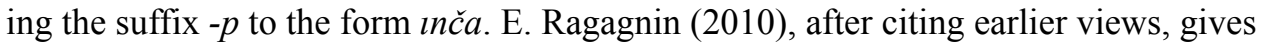
examples from northeastern Turkic languages and provides names derived from the Sayan Turkic verbs of ınja- 'to act like that', minja- 'to act like this' and ganja- 'to act in which way, to behave how' and questions if these verbs used in Sayan Turkic were of ancient origins. (Also see DTS, p. 44.)

\section{3. aq1z- 'set against' (Tes N 3, Ta E 2).}

Tes N 3: boz oq bašin aquza učuz kälkä atlıүın tökä barmıš “(He) set (leader of) Grey Arrow(s) against (the enemy), dumped (them) into Lake Učuz (with) their horses".

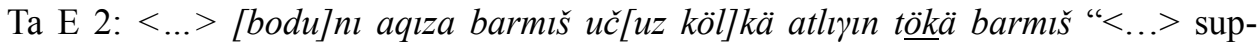
pressed the people, dumped (them) into Lake Učuz with their horses".

In runic texts, the verb $a q$ - does not occur. However, since the derivatives of the verb $a q$-were used, it should have existed in that period. For example, aqut- 'to make someone to raid' (KT N 8, T 35). In the name aqinču alp bilgä čigši observed in the first line of the north face of the Ta inscription, the word aqinču should have been formed by adding $-(X) n c \breve{U}+$ suffix to the verb $a q$-. M. Erdal (OTWF, pp. 285-290) provides some examples for that suffix: alqınču, ärinčü, ınanču, ilinčü, qalinču, üzlünčü.

The verb aquz- made with the causative suffix $-z$ - and aqt- (KT and T) with the causative suffix - $t$ - were attested in two Uyghur inscriptions. It also occurs in Uyghur texts in the form aqlz-. The aqlt- 'can flow' form witnessed in TT III, 163 (BangGabain 1931, p. 465) demonstrates that this is the original meaning of the verb aqut-, but it should be added that this form, used in the runic period, was a literary expression in a figurative meaning. Tekin (1990, p. 392) admitted that he misread the same expression in the Ta inscription and concluded that the correct form should be aquz-, with the addition of the gerundial suffix - a, aqıza (see also Tekin 2003, p. 237).

In the following epochs of Turkic the causative form of the verb $a q$ - was used only with its basic meaning. For example, in the Lugat-i Nevaiyye in entries aqlzdl, aqızliy, aqızmaq and aqızur, the causative form of the verb aq-is apparent and its meaning is 'flow of the water' (Kaçalin 2010, p. 132).

If there is no mistake in reading the letters of the verb aquz-and the adverb $a q ı z a$, it is a significant finding for the vocabulary of the Uyghur inscriptions.

4. arqar 'the mountain sheep' (ŠU S 1).

ŠU S 1: ärtiš ügüzüg arqar bašl tušl anta är qamıš altın . [ya] $\underline{n t a} s<\ldots>p$ käčdim "At the junction(?) (of) Irtysh River (called) head of Arqar, there made of cane, down under $<\ldots>$ I passed".

Among the runic texts the word occurs only in ŠU S 1. It was used in the placename arqar bašı and read by everbody in this way (Aydın 2011a, p. 78).

According to Doerfer (TMEN I, No. 12) the word was borrowed into Mongolian from its form arqarl 'sein Wildschaf', and thence into Manchu as aryali 'weibliches Wildschaf, Ovis ammon'. It is worth mentioning that this animal did not live in 
the steppes, but in higher mountains like Altai and Khangai and could not be found in certain mountains of Mongolia, e.g. Khentii Mountains. Clauson (ED, p. 131a) mentioned that the missing phrases in the section är qamiš altın .nta s..p could be complemented as yanta sallap the meaning of which would be "putting the men on rafts below the reeds". In the entry baš, he interpreted arqar bašl as 'the mountain sheep's head' (ED, p. 375a-b) and assigned the meaning 'the mountain sheep, Ovis argali' to the word arqar Clauson (ED, p. 216b). He also cited the form found in ŠU inscription, adding that the Mo. word aryali was borrowed from Turkic. DTS (p. 54) refers also to the word arqar mentioned by Kāshgharī: 'архар, аргали, горный баран'.

For arqar, mentioned in ŠU inscription, Kāshgharī construed 'boynuzundan bıçak yapılan dişi dağ keçisi: female mountain goat, whose horns were used to produce knives' (Atalay 1992/I, p. 117, 214, 421). Also see: arqaryalca 'species of deer'. It is a species of red deer: 'k1z1l keyik' (Pavet de Courteille 1972, p. 14), arqa yalča 'a species of red deer' (ک̌S, p. 9). The difference between Pavet de Courteille and ŠS might be due to a misspelling. In The King's Dictionary (Golden 2000, p. 220), arqar was mentioned as a Tu. and Mo. word. In modern Turkic languages; Kirg. arxar 'female of mountain goat' (Yudahin 1988, p. 47), Alt. arqar 'wild sheep' (Baskakov-Toshchakova 1999, p. 28) and Uyg. arhar 'wild sheep' (Necip 1995, p. 16) forms survive. Although the form arqar is not observed in Turkish and its dialects spoken in Turkey today, aryali 'wild sheep' used in Turkish is related to arqar: aryall 'yaban koyunu, dağ koyunu, dağ keçisi: wild sheep, mountain sheep, mountain goat' (Toven 2004, p. 32), aryall 'yabani koyun: wild sheep' (Kestelli 2004, p. 16). H. Eren (1999, pp. 16-17) reports that the name of the animal he describes as 'Sibirya ve Orta Asya'da yaşayan, büyük boynuzları olan yaban koyunu (Ovis argali): wild sheep (Ovis argali) with large horns living in Siberia and Central Asia' was originally Mongolian, however, aryali came from Turkic arqar; and Fars. āryālì came from Mongolian. Vgl. aryall 'das argali-schaf, wilde gems' < Otü. arqar (Ramstedt 1976, p. 13). The word is used in Mongolian writing as aryali: 'Argali, mountain sheep (female)' (Lessing 1960, p. 52). (See also VEWT, p. 26; Aydın 2008, pp. 202-204; 2012, pp. 45-47.)

\section{5. ayur 'narrator, teller' (Ta N 5, 5).}

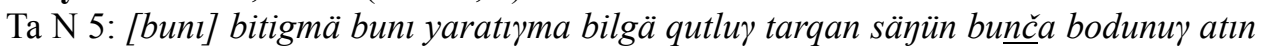

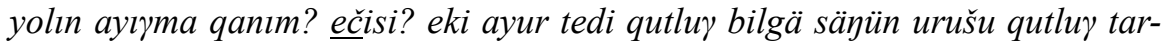
qan säyün ol eki ayur "whoever writes ('tis), creates 'tis (is) Bilgä Qutluy Tarqan Sängün. Two narrators? told (narrated), (who were) the uncle(s) of the my khan?, who said (narrated) the names, reputations of all these clans. These two

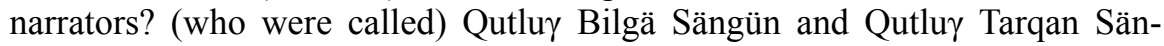
gün".

This form found in Ta inscription was presented at the international symposium organised in Ulaanbaatar during August 15-16, 2011 entitled "The Progressive Epochs of Turkish Culture: The Age of the Beginnings and Inscriptions" in this author's presentation "New Reading and Interpretation Proposals for the 5th Line of the Northern Side of the Tariat Inscription". The word found in the middle and at the end of the 
line was interpreted by Kljaštornyj (1982, pp. 342, 345) as ol-eki yor "these two (persons)", Tekin (1983, pp. 807-811) as ol eki yur "these two brothers in law", Kljaštornyj (1988, p. 277) as ol-eki yor "to two (persons)", Katayama (1999, p. 170, 172) as ol eki yur "these two men are brothers-in-law(?)". As could be understood by the readings, the word $y u r$ was interpreted as yurc 'brother-in-law.' The fact that the word meaning 'brother-in-law' is yurc forced the publishers to add a question mark next to the interpretation. It is very unlikely that the scribe made a mistake in a word used twice in the same line by omitting the final $-\check{c}$ twice. The word does not have a meaning when read as yor or yur. If the word is prefixed with an $A$, it would turn into ayur, then it would have the meaning of 'narrator'. Since the line speaks about the maker, writer and narrators of the inscription from the beginning, it could be appropriate to interpret the word ayur as the 'narrator.' It could also be interpreted that the word ayur was created from the verb ay- by using the $-(U) r+$ suffix to create an adjective from a verb. Gabain $(1950, \S 128, \S 150)$ gives numerous examples of words constituted by using the suffix $-r$ to create deverbal nouns and adjectives: tilär 'Gottesanbeterin (tilä- 'bitten')', ot öčüri 'des Feuers Verlöschen', ögdir 'Preis' and säwär 'lieb', učar 'fliegender', közünür 'erscheinender, augenblicklicher'. This word that we proposed to read and interpret as ayur 'narrator', has not yet been attested in any text.

6. bälgü 'stamp' (Tes S 3, Ta W 2, ŠU E 8, 9).

Tes S 3: bälgüsin bitigin bo urtı bo yaratdl "That (person) deserved his stamp and scripture and that (person) created".

Ta W 2: big yll<l>iq tümän künlük bitigimin bälgümün bunta "my writing and stamp (destined to last for) one thousand years (and) ten thousand days, here".

ŠU E 8: bälgümün bitigimin anta yaratıtdım "I created there my stamp (and) my writing".

ŠU E 9: bıฤ yıllıq tümän künlük bitigimin bälgümün anta yası tašqa "my writing and stamp (destined to last for) one thousand years (and) ten thousand days, there on the flat stone".

The word was not attested in any runic text other than the Uyghur Khanate inscriptions. Doerfer (TMEN I, No. 94) states that the word could be early Turkic *bälgö. Fundamentally, the main point made by Doerfer is the fact that the word passed on to the European languages from Turkic. Clauson (ED, p. 340a) interpreted it as 'sign, mark' and stated cautiously that it could be bälgö and the Mongolian form was borrowed from Turkic. Clauson provides the example in Toyok text from Orkun (1938, p. 58) and the example in ŠU inscription. (For Toyok text, see also Yildirım 2013, p. 454.) It has been used as bälgü in other historical periods of Turkish (ED, p. 340a). Räsänen (VEWT, p. 69) accepts the word as originating from the root *bäl and gives examples from other Turkic languages. (For Mongolian forms see Ramstedt 1976, p. 46.)

The word tamya 'stamp' could not be found in runic texts, however, the word tamyačl (KT N 13,13) occurs. The fact that the word bälgü appears in Uyghur inscriptions instead of tamya could be interpreted as a dialectal factor. 
7. bältir '(river) junction' (ŠU E 9, ŠU S 10).

ŠU E 9: yawaš toquš bältirintä anta yayladım "I spent the summer at Yavaş and Tokuş (rivers) junction".

ŠU S 10: orqon balıqly bältirintä el örginin anta örgipän etitdim "I built and arranged the throne (administrative centre) of the country at the junction of Orkhon (River) (and) Balıqli (River)".

No specimens were found in the runic texts other than the two above. Clauson (ED, p. 334a) interprets the word as 'the junction of two or more rivers' and states that it was borrowed into Mongolian as bälčir. Clauson, referring to Radloff, states that it was borrowed into northeastern Turkic languages as pältir and enumerates the examples of Khak. piltir, Tuv. bäldir and the examples in ŠU inscription and also provides examples from Uyghur and Karakhanid. We can learn from Kāshgharī 's (Atalay 1992/I, p. 456) data (tay bäldiri) that the word was not only used to describe river junctions, but the meeting point of the mountains were also called bältir $\sim$ bäldir. Räsänen (VEWT, p. 69) interprets the word with the wide meaning of 'Kreuzweg' and refers to other Turkic languages as well. The initial meaning of the word must have been 'the meeting point of two rivers' as can be seen from the Mo. bälčir (see also Ramstedt 1976, p. 42).

8. bošun- 'escape, to break free' (ŠU E 7), bošunul- 'escape, to break free' (ŠU E 7).

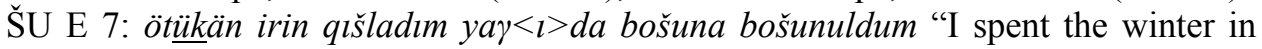
northern Ötüken. I escaped from the enemy (and was) at ease".

The word was not attested in other runic texts. Clauson (ED, p. 383a-b) considers the verb as the reflexive form of bošu:-. He interprets that example in ŠU inscription as yayıda bošuna bošunladım. He provides examples from later periods in the form of bošan-. In the entry for bošun- in DTS (p. 115) the above example from ŠU inscription was not included. It is obvious that the verb was formed from the noun boš 'empty' (VEWT, p. 82). Tietze (2002, p. 303) treated the verb bošan- under two different headings: bošan- (1) 'kendini bir yerden kurtarmak = to save one's self from a place', (2) 'kocası tarafindan bırakılmak; eşinden ayrılmak = left by her husband: to be separated from the partner'. It is not quite understandable why Tietze considered the basically same meanings of the verb in two different entries.

9. čıt 'fence, border stones or pegs surrounding the military quarters' (Tes S 2, Ta W $1,2, \breve{S} U$ E 8, 9, ŠU S 2).

Tes S 2: < ..> [tä]zig qasar qur $<l>\gamma$ qontı člt tikdi “ $<\ldots$..> Settled on Tes (River's) (source?), West of Kasar. Built fence".

Ta W 1: örgin [anta etitdim čtt] anta yaratıtdım "(There I made them set the) throne, (and) made them stroke (the fence) there".

Ta W 2: örgin bunta yaratı $<t>d i m$ člt bunta toqutdım "Here I made them set the throne, (and) made them stroke the fence here".

ŠU E 8: örgin anta etitdim člt anta toqutdim "There I made them set the throne, (and) made them stroke the fence there". 
ŠU E 9: örgin anta yaratıtdım člt anta toqutdım "There I made them set the throne, (and) made them stroke the fence there".

ŠU S 2: täz bašı čıtımın ${ }^{2}$ yayladım "(I made them construct) my fence at the source of the (River) Tes and spent the summer (there)".

Doerfer (TMEN III, No. 1152) designates the word as čet and does not mention any example from the runic period. He provides examples only from other periods and the modern Turkish language. In his entry on the word, Clauson (ED, p. 401b) sets the vowel as $l$, but states it was written also as $i$ and $\ddot{a}$, and in addition to the ŠU inscription puts forward examples from different periods of Turkic. As Clauson mentions, originally the word had a velar vowel, but in the subsequent periods it was also written with a front vowel as $\ddot{a}$ or $i$. (See also Eren 1999, p. 95; Tietze 2002, p. 455.)

10. egil '(ordinary) people' (ŠU E 2).

ŠU E 2: qara egil bodunuy yoq qulmadim "I did not annihilate the ordinary people (commons)".

The word occurs only once in runic texts. By pointing at the specimen in $\breve{S} U$, Clauson (ED, p. 106a) gives the definition of 'common, ordinary, lower class' and states that the Mo. form is ägäl. Gabain (1950, p. 310) assigns the meaning of 'umumî, dünyevî = public, earthly' to the word. It is a word that has not been attested in any other runic texts, but used solely in the Uyghur inscriptions. (See also DTS, p. 204.)

11. Ilay 'valley, pasture' $(\mathrm{Ta} \mathrm{W} 4,5)$.

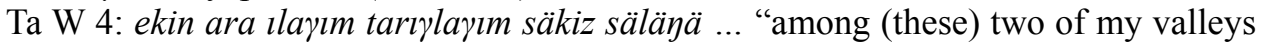
(and) my fields eight (armed) Selenge (River)..."

$\mathrm{Ta} \mathrm{W} 5$ : $<\ldots>$ ič llaylm ötükän yiri ongl tar[qan] süy ... " $<\ldots>$ my inner pasture Ötüken, in the north Ong1 Tarkan Süy..."

The word in the 4th line of the inscription was read as llyım by Šinekhüü and Kljaštornyj, and as Ilyam by Tekin and Berta; the example in the 5th line of the Ta

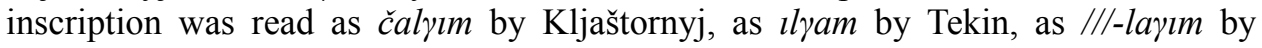
Katayama, and as ...lym by Berta.

Tekin (1983, p. 818) mentions in his notes that the word after ulay is tartylay, and the one before it should be a word that could form hendiadys and he states that it could be yllya, cllya 'river'. As far as I know, the first person who read the word in the right way was Katayama (1999, pp. 168-176). In his paper about this word, S. Şen (2010, pp. 105-106) states that by opening it up as $\imath+l a \gamma$ and identifying it as 'woodland, copse' and forming reduplication with tariplay, it should therefore be understood as 'my lands'. He also states that there are several examples of $l$ tarl $\gamma$ reduplication in Uyghur texts, however, llay tarlylay reduplication was not seen in these texts. For the suffix $+l A G$ in the word, see OTWF pp. 108-109. The word has not been attested in the runic period texts or in any other periods of Turkic.

12. küt- 'to wait' (ŠU E 5).

ŠU E 5: eki ay kütdüm kälmädi "Two months I waited (for them but) they did not come". 
Clauson (ED, p. 701a-b) identified it as $k \ddot{u}: \delta$ - meaning 'to wait' and 'to wait for (someone Acc.)'. Clauson stated that the origin of the verb was $k \ddot{u} \delta$ - and evolved via the $-\delta->-d->-t$ - change into the verb küt- and provided examples from northeast and southeast Turkic languages. The fact that the word was seen in Uyghur texts with the consonant $\delta$ should have forced Clauson to write about this transformation. However, the specimen in ŠU was written with a $t$. Clauson also mentioned a discrepancy between the printed text and the facsimile for $\breve{S} U$. He also provides samples that it was observed in $k \ddot{u} \delta$ - and $k \ddot{u} z$ - forms in later periods of Turkic. It is obvious that in certain periods of Turkic, there were examples with $t, \delta, z$ and $y$ sounds. Erdal (OTWF, pp. 196, 375-376 and 808) also accepts the verb as kü $\delta$-. (See also DTS, p. 324.)

13. ödkünč 'false, fake' (Tes E 2).

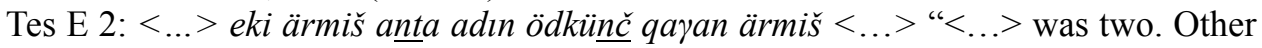
than that (one of them) was the false khan $<\ldots>$ ".

This is a rather debated text and read in different ways by different publishers of the inscription. Kljaštornyj read it as $\ddot{o} d k \ddot{a n} n \check{c}$, and Berta as $\ddot{o} \delta k \ddot{w} n$, while Tekin (1990, pp. 394-395) read and interpreted the word quite differently. Tekin considered the word as ödkünč 'fabrication, fake' and wanted to connect it to the verb ödkün- 'to imitate' known from other Turkic texts. According to Tekin, the word occcurs twice in the Kutadgu Bilig, but Arat read it as ödgünč and Clauson followed his suit. Tekin considers it one and the same with Osm. and Čag. öykün- 'to imitate'. According to Tekin, Šor and Sag. öktän- and öktön- are metathetical forms and Yak. ütügün- also goes back to the verb ödkün-. (For the examples in Kutadgu Bilig, see Arat 1979, p. 366; and for Clauson's ötgünç and ötgün- forms, see ED, p. 52a.) Erdal (OTWF, p. 277) also thought, in a cautious way, that the original form of the word could be * ödkün-. Gülensoy (2007, p. 657), in his description of the item ökün-, compared it with ökün- 'to regret' and ökünč 'remorse'. But ökün- 'to regret' is another verb, and ökün and öykün- 'to imitate' go back to the verb * ödkün-. This is corroborated also by Tel. öktön- 'to imitate'.

14. örgi- 'to establish a throne' (ŠU S 10).

örgin 'throne' (Tes S 2, Ta S 6, Ta W 1, 2, ŠU E 8, 9, ŠU W 6, ŠU S 10).

ŠU S 10: el örginin anta örgipän etitdim "I had the throne (administrative centre) of the country established there and had it put in order".

Tes S 2: člt tikdi örgin yaratd yayladl "He built fence, established the throne, (and) spent the summer (there)".

Ramstedt (1913, p. 53), compares the word örgin with Mo. örgügä and *örgü-. See Mo. örgägä / örgögä 'residence or tent of a prince, palace of a khan or a person of rank, etc.' (VEWT, p. 374). Clauson (ED, p. 225b) relates the word to the verb örg $\ddot{a}$ and gives the meaning 'throne'. On the other hand, L. Clark (1977, p. 142) takes the root of the word that he considers Mongolian from the verb ör- 'to rise', assumes that the $-\gamma$ in / -gin suffix functioned as a deverbal suffix and compares it with the words tér- 'to gather together' > térgin 'gathered together, a concentration'; yel- 'to trot, 
amble' > yelgin 'one who rides fast, traveller'; kev- 'to chew' > kevgin 'indigestible food (which must be chewed thoroughly)'. It is obvious that the word örgin used to designate the tent of the khan, built a little higher than the ground, can be derived from the verb örgi- 'to raise', since the verb örgi- appears once in ŠU S 10. Clark's idea that it was derived from the verb $\ddot{o r}$ - by using the deverbal suffix -Gın, does not seem to be convincing. Furthermore, O. N. Tuna (1957, p. 67) assigns the meaning 'yığma tepe = stockpiled hill' to örgin, which is not possible. (See also Menges 1958; Esztergár 1963, p. 39; Erdal 1978, p. 88.)

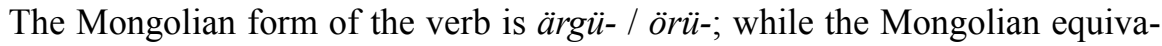

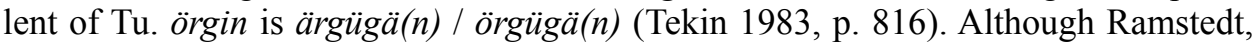
Räsänän and Clark argued that the word was originally Mongolian, I think it was the other way round: the Turkic word was borrowed into Mongolian.

15. suqaq 'female deer' (ŠU S 11).

ŠU S 11: qara buluq öy[dü]n suqaq yull anta čigil totoq $<\ldots>$ "To the east of Qara Buluq, at Sukak Yulı (Gazelle Spring, Deer Spring), the military governor of the Čigil(s) < ... >".

Various studies read the phrase as follows: Ramstedt (1913, p. 31) sooqaq yolı 'Sokak-weg'; Orkun (1936, p. 178) sokak yolı 'Sokak yolu = Sokak way'; Malov (1959, pp. 37, 42) Soqaq ( Šoqaq) yoll 'дорога ( речка) Сокак’; Moriyasu (1999, pp. 181, 185) suqaq yull 'Sukak-Yulı'; Berta (2004, pp. 296, 311) sokwk yoll 'Szokuk útja'; Aydın (2007, pp. 51, 62) suukak yulı 'Sukak Yulı (Ceylan Pınarı; Geyik Pınar1)', and Ölmez (2013, pp. 298, 304) su' kak yull 'Sukak Pınarı'.

Clauson (ED, pp. 808a, 918a) explains the meaning as 'female gazelle'. Kāshgharī (Atalay 1992/I, p. 214; 1992/II, p. 287) gives the word as suqaq 'sı̆ğn, geyik,

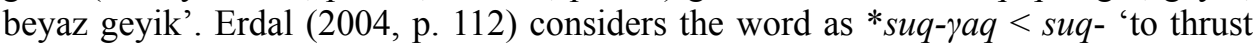
(with the horns)'. The word has been used in other Turkish language periods: suqaq 'beyaz geyik' (Ş. Tekin 1976, p. 461), suqay 'a large deer species whose horns are used to make knife handles; narrow street' (Pavet de Courteille 1972, p. 357), suqay 'bir nevi büyük geyik' (ŠS, p. 191), sokak 'ala renkli geyik' (Toparlı-Vural-Karaatl1

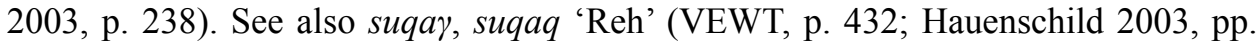
189-190; Aydin 2007, pp. 95-96; 2008, p. 204; 2012, pp. 152-153).

16. šıp (sıp?) 'colt?' (ŠU E 3, 4).

ŠU E 3: säläyä kedin yılun qol ber $<i>$ din šıp bašına tägi čärig etdim "To the west of Selenge (River), from the southern tip of Y1lun-Kol to the source of Şıp (River), I deployed soldiers".

ŠU E 4: kärgün saqišın šlp bašın körä? kälti "The enemy came seeing? Kergü, Saqı̌̌ and Šp (River) source".

This word was observed twice in runic texts. In Kāshgharī, it was mentioned as sıp 'iki yaşına girmiş olan tay = two-year-old colt' (Atalay 1992, Vol. I, pp. 207, 319; 1992, Vol. III, p. 158); sip aqur 'hayvan torbas1 = animal bag' (Atalay 1992, Vol. I, p. 487); sıp aqurı 'hayvan torbası; iki yaşındaki tayın yem yediği yer = animal bag; the bag two years old colt eats from' (Atalay 1992, Vol. I, p. 487). Clauson (ED, 
p. 375a) reads it in conjunction with the subsequent word as sip baš meaning of 'the colt's head' to the word. In the item sip, he gives the meaning of the word as 'a one-year-old colt' and compares it with sipa 'a donkey colt from six months to a year' (ED, p. 783a). Eren (1999, p. 365) mentions that the final $-a$ of sipa is a suffix and could have been formed similarly to buyra. He also points to the fact that in modern Turkish languages different words were used to denote 'colt' and sipa has a rather limited meaning. (See also Hauenschild 2003, pp. 185-186; Aydin 2007, pp. 78-79; 2008, pp. 204-205; 2012, p. 135.)

\section{7. tapıg 'service' (ŠU W 5).}

ŠU W 4-5: eki quzın tapı $\gamma$ bert [i] "He performed service with two daughters".

The word occurs only once in the runic texts. According to Clauson (ED, p. $437 \mathrm{a}-\mathrm{b})$ the verbal root of the word tapı 'service' is tap- and enumerates examples from Uyghur and later Turkic texts (see also TMEN Vol. II, No. 849; DTS, p. 534; Erdal 2004, p. 420).

\section{8. tariylay 'field' (Ta W 4).}

The word tarlylay that could be observed with llay (see above) in the 4th line of the western side of the Ta inscription is a well-known and commonly attested word. However, early publishers have read it in a different way (see Tekin 1983, p. 818). For the suffix $+l A G$, see OTWF, pp. 108-109; see also ED pp. 541b-542a. Certain studies proposed that the word tarlay observed in the Yenisei inscriptions Ald11-Bel I (E 12) 2nd line, Ald11-Bel I (E 12) 3rd line and Ald11-Bel II (E 72) 1st line also meant 'field', e.g. Orkun 1940, p. 53. However, the word tarlay in the Yenisei inscriptions did not mean 'field', but the name of the river Tarlaq (see Aydin 2011b, pp. 254-255; 2012, pp. 114-115).

\section{9. tayyan 'hound, hound dog' (ŠU S 3).}

ŠU S 3: tayyan költä teriltim "I gathered at Taygan Lake (again)".

This word occurs once as a place-name in the runic texts. It is quoted in Kāshgharī (Atalay 1992, Vol. I, p. 421; 1992, Vol. II, pp. 15, 343; 1992, Vol. III, pp. 174,

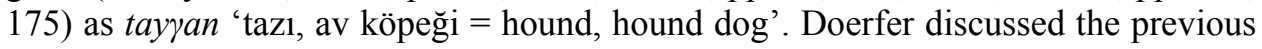
etymologies of the word, especially Ramstedt's comparison of Mo.-Tü. tay and Kor. * kańi, and noted that the word was formed from the verb tay- 'to slide' that was used in Southern Siberian Turkic languages, then borrowed into Mongolian as tayiga, and from Mongolian to Manchu as taiha. However, Doerfer (TMEN Vol. II, No. 866) did not relate the word to the place-name tayjan köl in ŠU. Räsänen (VEWT, p. 456) proposes an interesting etymology for tayjan: Mo. *tayi 'forest' + Tü. *qan 'dog'. Clauson (ED, p. 568b, 715a) defines it as an animal name formed with the $-G A n$ suffix and meaning 'greyhound, borzoi', however, he does not relate the word to tayjan köl in ŠU. Clark (1977, p. 154) thought the word was Mongolian: tayjan 'greyhound'. Erdal (OTWF, p. 88) derives the word tay an from the verb tay- 'to slip by, to slip down, to glide along' supplied with the suffix -GAn. We can subscribe to Erdal's opinion since the verb tay- was widely used in historical and modern Turkic 
languages with several meanings, but especially with the meaning 'to slip'. (For examples and details, see Aydın 2008, p. 205; DTS, p. 528; Aydın 2012, pp. 165-167.)

20. toytar- 'bring down, topple' (Ta E 8).

Ta E 8: $<\ldots>$ anta toytartim qan [in altim] " $<\ldots>$ there I brought it down (toppled) and I captured the Khan".

This word, observed only in the 8th line of the east face of the Ta inscription, was read and interpreted by Kljaštornyj as toqttıtım, by Tekin as toqtartım, and by Berta as tonDarDım[?] (Aydın 2011a, p. 44). Erdal (OTWF, p. 738, note 463) read and interpreted the word as toytartim 'I overturned'. Clauson (ED, p. 518b) connected the verb tontar- to the verb töydär- and stated that in that case it was the causative form of the verb tönit-.

21. utru 'opposite, opposite side' (ŠU S 3).

ŠU S 3: qara yotulqan käčip kälirti bän utru yorldım "(He said that) he passed Kara Yotulkan and brought (?). I moved (towards) the opposite side".

This word occurs only once in the runic texts. It was read the same way by all studies on the ŠU inscription (Aydın 2011a, p. 80). Clauson (ED, p. 64a-b), identified it as an adverb formed from the verb *utur- and quoted the examples in the ŠU inscription, the Irk Bitig and other sources. Tekin (1978, pp. 37-38) connected it with Mo. uүtu- 'karşılaşmak, gelen komşuyu karşılamak ya da kabul etmek, beklenen bir konuğu karşılamak = to welcome, to welcome or accept a visiting neighbour, to welcome an expected guest' and envisaged the following development: utru $<* u t u r-$ $<u t-u r-<* u q t-<* u q t \breve{u}$. According to Erdal $(2004$, pp. 333, 408) it can be associated with Yak. utar-and *ut-ur (see also OTWF, p. 741).

22. yamaš- 'to join' ( $\mathrm{Ta} \mathrm{E} 6)$.

Ta E 6: < ..> atllyın yamašdl "< .. > joined (us) with his horsemen".

Tekin (1983, p. 813), in his paper where he published the Ta inscription, criticised Kljaštornyj's reading and interpretation as yumšadl 'sent' and stated that the verb was formed using the verbal root yama- and the reciprocal suffix $-\check{s}$ - and gave the example of modern Turkic (Uyg., Uzb.) yamaş- 'katılmak, iltihak etmek, birleşmek $=$ to join, to adhere, to unite'. The word was not mentioned in ED and DTS. In both dictionaries the verb yamaš- was related to Kāshgharī's example of ol ayar ton yamašdl, which is the modern Turkish verb of yama- 'to repair with a patch' (DTS, p. 231; ED, p. 939a).

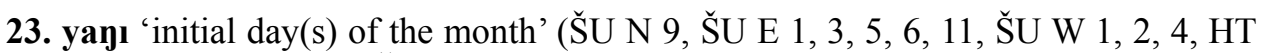
$\mathrm{VI} / 4, \mathrm{HT}$ XV/2, QČ 17).

ŠU E 3: törtünč ay toquz yayıqa süyüšdüm "I waged war on the ninth day of the fourth month, was lanced".

HT VI, 4: bir yegirmikä ay bir yayıqa ayay (?) $k^{2}$ "First day of the eleventh month, respect (?)". 
HT XV, 1-3: 1. bečin yılqa, 2. toquzunč ay eki yayıqa, 3. bardımız "1. In the year of the monkey, 2. on the second day of the ninth month, 3. we went (arrived)".

QČ 15-16-17: layzın yıl altınč ayqa yeti yayıqa "on the seventh day of the sixth month of the year of the pig".

The word can also be found in the 17th line of the recently discovered Uyghur epitaph in Xi'an. However, it does not occur in any other runic texts. If so, it could rightly be supposed that the Hoyto-Tamir VI and XV inscriptions were also written in the Uyghur dialect.

Clauson (ED, pp. 943b-944a) gave the meaning of the word yay $\iota$ as 'new' and stated that it had substantial and abstract uses. Clauson, after defining the word, claimed that the word had the meaning of 'one of the first ten days of the month' in Uyghur texts and quoted examples from the ŠU inscription. However, the other specimens he mentioned were all related to the word's meaning of 'new'. DTS (p. 234) provides it as the second meaning in the entry. (See also Erdal 2004, p. 227.) The word continued to be used in Uyghur texts, but in the great inscriptions of the Second Turk Khanate the word kün was used instead. So this special usage of yayı can be tentatively connected to Uyghur.

24. yoluq- 'encounter, come across' (ŠU S 1).

ŠU S 1: bir yegirminč ay säkiz yegirmikä <...> yoluqdum "on the eighteenth of the eleventh month $<\ldots>$ I came across".

The word occurs once in the runic texts, see DTS p. 272. It is not mentioned by Clauson in ED.

\section{Conclusion}

Twenty-four words were discussed in this paper. There exist a few more examples that, owing to certain reading problems, were excluded from the sphere of investigation. The fact that those twenty-four words are attested only in Uyghur inscriptions, and they are replaced by other words in other runic inscriptions, prompted us to conclude that the discussed words may have been of Uyghur dialectal descent. We are convinced that a few more words will crop up in the future demonstrating that Uyghurspeaking people could have written those inscriptions. In the 8th century, similarly to the modern period, different Turkic words could have existed side by side with the same or similar meanings, and these dialectal features may help identify the people or clan that erected and wrote the related inscriptions.

\section{Abbreviations}

\section{Inscriptions and Aspects}

E East (the face of the inscription)

KT Köl Tegin inscription

$\mathrm{N} \quad$ North (the face of the inscription) 
QÇ Qarı Čor (Xi'an) inscription

$\mathrm{S} \quad$ South (the face of the inscription)

ŠU Šine Usu inscription

$\mathrm{T}$ Tonyukuk inscription

Ta Tariat inscription

W West (the face of the inscription)

\section{Languages}

$\begin{array}{ll}\text { Alt. } & \text { Altai } \\ \text { Čag. } & \text { Chagatai } \\ \text { Dolg. } & \text { Dolgan } \\ \text { Khak. } & \text { Khakas } \\ \text { Kırg. } & \text { Kirghiz } \\ \text { Kor. } & \text { Korean } \\ \text { Mo. } & \text { Mongolian } \\ \text { Osm. } & \text { Ottoman Turkish } \\ \text { Otü. } & \text { Old Turkic } \\ \text { Sag. } & \text { Sagai } \\ \text { Šor } & \text { Šor } \\ \text { Tel. } & \text { Teleüt } \\ \text { Tuv. } & \text { Tuvan } \\ \text { Tü. } & \text { Turkic } \\ \text { Uyg. } & \text { Uyghur } \\ \text { Uzb. } & \text { Uzbek } \\ \text { Yak. } & \text { Yakut }\end{array}$

\section{Bibliography}

Arat, R. R. (1979): Kutadgu Bilig. III Indeks. Prepared by Eraslan, K. - Sertkaya, O. F. - Yüce, N. İstanbul, Türk Kültürünü Araştırma Enstitüsü.

Atalay, B. (1992): Divanü Lîgat-it-Türk Tercümesi. 3 vols. Ankara, Türk Dil Kurumu.

Aydın, E. (2007): Şine Usu Yazıtı. Çorum, KaraM.

Aydın, E. (2008): Şine Usu Yazıtında Hayvan Adlarıyla Kurulmuş Yer Adları Üzerine İncelemeler. Turkish Studies, International Periodical for the Languages, Literature and History of Turkish or Turkic Vol. 3, No. 1, pp. 202-208.

Aydın, E. (2011a): Uygur Kağanlı̆̆ Yazıtları. Konya, Kömen.

Aydın, E. (2011b): Remarks on Qatun in the Yenisei Inscriptions. AOH Vol. 64, No. 3, pp. 251-256. Aydın, E. (2012): Eski Türk Yer Adlarl, Eski Türk Yazıtlarına Göre. Konya, Kömen.

Bang, W. (1980): Berlindeki Macar Enstitüsünden Türkoloji Mektupları (1925-1934). Translated by Tekin, Ş. Erzurum, Atatürk University.

Bang, W.-Gabain, A. von (1931): Analytischer Index zu den fünf ersten Stücken der Türkischen Turfan-Texte. Berlin.

Baskakov, N. A.-Toshchakova, T. M. (1999): Altayca-Türkçe Sözlük. Eds Gürsoy Naskali, E.Duranl, M. Ankara, Türk Dil Kurumu.

Berta, Á. (2004): Szavaimat jól halljátok ... A türk és ujgur rovásírásos emlékek kritikai kiadása [Closely listen to my words ... A critical editon of records in Turkic and Uyghur runic scripts]. Szeged, JATE. 
Clark, L. V. (1977): Mongol Elements in Old Turkic? JSFOu Vol. 75, pp. 110-168.

Clauson, G. (1972): An Etymological Dictionary of Pre-Thirteenth-Century Turkish. Oxford, Oxford University.

Doerfer, G. (1963-1975): Türkische und mongolische Elemente im Neupersischen. 4 vols. Wiesbaden, Franz Steiner.

DTS see Nadeljaev et al. (1969).

ED see Clauson (1972).

Erdal, M. (1978): Irk Bitig Üzerine Yeni Notlar. TDAYB Vol. 1977, pp. 87-119.

Erdal, M. (1991): Old Turkic Word Formation. A Functional Approach to the Lexicon. 2 vols. Wiesbaden, Harrassowitz.

Erdal, M. (2004): A Grammar of Old Turkic. Leiden-Boston, Brill.

Eren, H. (1999): Türk Dilinin Etimolojik Sözlüğ̈̈. Ankara, Türk Dil Kurumu.

Esztergár, M. (1963): Words Pertaining to Housing and Dwelling in the Altaic Languages. In: Sinor, D. (ed.): Aspect of Altaic Civilization (Proceedings of the Fifth Meeting of the Permanent International Altaistic Conference, Held at Indiana University, June 4-9, 1962). Bloomington, Indiana University, pp. 33-43.

Gabain, A. v. (1950): Alttürkische Grammatik: mit Bibliographie, Lesestücken und Wörterverzeichnissen, auch neutürkisch. Leipzig, Porta Linguarum Orientalium (2. verbesserte Auflage).

Golden, P. B. (2000): The King's Dictionary. The Rasûlid Hexaglot: Fourteenth Century Vocabulaires in Arabic, Persian, Turkic, Greek, Armenian and Mongol. Leiden, Brill.

Gülensoy, T. (2007): Türkiye Türkçesindeki Türkçe Sözcüklerin Köken Bilgisi Sözlüğü. Ankara, Türk Dil Kurumu.

Hauenschild, I. (2003): Die Tierbezeichnungen bei Mahmud al-Kaschgari. Eine Untersuchung aus sprach- und kulturhistorischer Sicht. Wiesbaden, Harrassowitz (Turcologica 53).

Kaçalin, M. S. (2010): Niyāzī, el-lugātu'n-nevā'iyye ve'l-istişhādātu'l-cagatā'iyye, Nevâŷ̂̀'nin Sözleri ve Çă̆atayca Tanıklar. Ankara, Türk Dil Kurumu.

Katayama, A. (1999): Tariat Inscription. In: Moriyasu, T. - Ochir, A. (eds): Provisional Report of Researches on Historical Sites and Inscriptions in Mongolia from 1996 to 1998. Osaka, The Society of Central Eurasian Studies, pp. 168-176.

Kestelli, R. N. (2004): Resimli Türkçe Kamus. Prepared by Toparlı, R. - Tezcan Aksu, B. - Kanoğlu, C. S. - Türkmen, S. Ankara, Türk Dil Kurumu.

Kljaštornyj, S. G. (1982): The Terkhin Inscription. $A O H$ Vol. 36, Nos 1-3, pp. 335-366.

Kljaštornyj, S. G. (1988): East Turkestan and the Kaghans of Ordubalyk Interpretation of the Fourteenth Line of the Terkh Inscriptions. $A O H$ Vol. 42, Nos 2-3, pp. 277-280.

Kormušin, I. V. (1997). Тюркские енисейские эпитафии, тексты и исследования. Moskva, Nauka.

Lessing, F. D. (1960): Mongolian-English Dictionary. Berkeley-Los Angeles, University of California Press.

Li, Y.-S. (2004): Türk Dillerinde Son Takılar. İstanbul (Türk Dilleri Araştırmaları Dizisi 40).

Malov, S. E. (1959): Памятники древнетюркской письменности Монголии и Киргизии. MoskvaLeningrad, Akademija Nauk SSSR.

Menges, K. H. (1958): A Note on the Compound Titles in the Proto-Bulgarian Inscriptions. Byzantion Vol. 28, pp. 441-453.

Moriyasu, T. (1999): Site and Inscription of Şine-Usu. In: Moriyasu, T. - Ochir, A. (eds): Provisional Report of Researches on Historical Sites and Inscriptions in Mongolia from 1996 to 1998. Osaka, The Society of Central Eurasian Studies, pp. 177-195.

Nadeljaev, V. M. - Nasilov, D. M. - Tenišev, E. R. - Ščerbak, A. М. (1969): Древнетюркский Словарь. Leningrad, Nauka. 
Necip, E. N. (1995): Yeni Uygur Türkçesi Sözlüğ̈̈. Translated by Kurban, İ. Ankara, Türk Dil Kurumu.

Orkun, H. N. (1936): Eski Türk Yazıtları. I. İstanbul, Türk Dil Kurumu.

Orkun, H. N. (1938): Eski Türk Yazıtlart. II. İstanbul, Türk Dil Kurumu.

Orkun, H. N. (1940): Eski Türk Yazıtları. III. İstanbul, Türk Dil Kurumu.

OTWF see Erdal (1991).

Ölmez, M. (2013): Orhon-Uygur Hanlı̆̆ı Dönemi Moğolistan'daki Eski Türk Yazıtları. Ankara, BilgeSu.

Pavet de Courteille, A. (1972): Dictionnaire Turk-Oriental. Amsterdam, Philo.

Ragagnin, E. (2010): Traces of Old Turkic ančip and ïnčip in Altaic Languages. In: Kappler, M.Kirchner, M. -Zieme, P. (eds): Trans-Turkic Studies. Festschrift in Honour of Marcel Erdal. İstanbul (Türk Dilleri Araştırmaları Dizisi 49), pp. 299-314.

Ramstedt, G. J. (1913): Zwei uigurische Runeninschriften in der Nord-Mongolei. JSFOu Vol. 30, pp. $1-63$.

Ramstedt, G. J. (1976): Kalmückisches Wörterbuch. Helsinki, Lexica Societatis Fenno-Ugricae.

Räsänen, M. (1969): Versuch eines etymologischen Wörterbuchs der Türksprachen. Helsinki, Lexica Societatis Fenno-Ugricae.

Röhrborn, K. (1977-1998): Uigurisches Wörterbuch. Sprachmaterial der vorislamischen Türkischen Texte aus Zentralasien. Wiesbaden, Franz Steiner.

Şen, S. (2010): Taryat Yazıtının Batı Yüzünde $I L G M$ ve $L G M$ İşaretleriyle Yazılan Sözcük Nasıl Okunup Anlaşılmalı? TDAYB Vol. 2008/II, pp. 99-107.

Şeyh Süleyman Efendi-yi Buhârî (1298 AH): Lugat-i Çağatay ve Türkî-yi Osmanî. İstanbul, Mihran.

ŠS see Şeyh Süleyman Efendi-yi Buhârî (1298 AH).

Tekin, Ş. (1976): Uygurca Metinler II: Maytrısimit, Burkancıların Mehdisi Maitreya İle Buluşma, Uygurca İptidaî Bir Dram. Ankara, Atatürk University.

Tekin, T. (1978): Ön Türkçede Ünsüz Yitimi. TDAYB Vol. 1977, pp. 35-51.

Tekin, T. (1983): Kuzey Moğolistan'da Yeni Bir Uygur Anıtı: Taryat (Terhin) Kitabesi. Belleten Vol. 46, No. 184, pp. 795-838.

Tekin, T. (1990): Tes Yazıtı Hakkında Dokuz Not. Translated to Turkish by Çelik, Ü. Erdem Vol. 5, No. 14, pp. 389-398.

Tekin, T. (2003): Orhon Türkçesi Grameri. İstanbul (Türk Dilleri Araştırmaları Dizisi 9).

Tietze, A. (2002): Tarihi ve Etimolojik Türkiye Türkçesi Lugatı. Vol. 1. İstanbul-Wien, Simurg.

TMEN see Doerfer (1963-1975).

Toparl1, R. - Vural, H. - Karaatlı, R. (2003): Kıpçak Türkçesi Sözlüğü. Ankara, Türk Dil Kurumu.

Toven, M. B. (2004): Yeni Türkçe Lügat. Prepared by A. Hayber. Ankara, Türk Dil Kurumu.

Tuna, O. N. (1957): Bazı İmlâ Gelenekleri Bunların Metin İncelemelerindeki Önemi ve Orhon Yazıtların'da Birkaç Açıklama. TDAYB Vol. 1957, pp. 41-81.

Tybykova L. N.-Nevskaja, I. A.-Erdal, M. (2012): Каталог древнетюркских рунических памятников Горного Алтая. Gorno-Altajsk, Gorno-Altajskij Gosudarstvennyj Universitet.

UW see Röhrborn (1977-1998).

VEWT see Räsänen (1969).

Yıldırım, F. (2013): Kâğıda Yazılı Runik Harfli Eski Türkçe Metinler. In: Yenisey-Kırgızistan Yazıtları ve Irk Bitig. Prepared by Aydın, E.-Alimov, R.-Yıldırım, F. Ankara, BilgeSu, pp. 339-494.

Yudahin, K. K. (1988): Kırgız Sözlüğü. Translated by A. Taymas. Ankara, Türk Dil Kurumu. 